\title{
An uncommon cause of leg oedema
}

\author{
Tomoko Naito, Hideharu Hagiya, ${ }^{\circledR}$ Futoshi Nakagami, Koichi Yamamoto
}

Department of General Internal Medicine, Osaka University Hospital, Suita, Osaka, Japan

\section{Correspondence to}

Dr Hideharu Hagiya,

e_dai_for_all@hotmail.com

Accepted 5 January 2019
Check for updates

(C) BMJ Publishing Group Limited 2019. No commercial re-use. See rights and permissions. Published by BMJ.

To cite: Naito T, Hagiya $H$, Nakagami F, et al. BMJ Case Rep 2019;12:e228888 doi:10.1136/bcr-2018228888

\section{DESCRIPTION}

A 78-year-old previously healthy woman on no medical treatment suffered from bilateral leg oedema lasting more than 6 months. Although the patient had undergone close investigations at two other medical institutions, an exact reason was uncertain. She was prescribed loop diuretics under a tentative diagnosis of idiopathic lymphoedema. However, the treatment was ineffective, and she was referred to our hospital.

At the time of presentation, her vital signs were within normal range and did not suggest hypertension. She had no relevant medical history including abdominal surgery. Except for the bilateral non-pitting oedema (figure 1), physical examination did not reveal any remarkable findings. Results of investigations for cardiac, renal and thyroid function were normal. A contrast-enhanced CT did not reveal suprarenal artery stenosis. A venous and lymphatic duplex Doppler ultrasonography was not performed. Instead, considering an uncertain fasciitis, the patient was sent for MRI of lower extremities which showed diffuse oedematous changes in the subcutaneous tissue of the bilateral thigh and lower limbs (figure 1). Laboratory investigations revealed hypokalaemia (3.4 $\mathrm{mEq} / \mathrm{L}$ ), and we considered primary aldosteronism as an origin of the persistent leg oedema. Her aldosterone-to-renin ratio was 311 (plasma aldosterone concentration (PAC) $124.4 \mathrm{pg} / \mathrm{mL}$; plasma renin activity (PRA) $0.4 \mathrm{ng} / \mathrm{mL} / \mathrm{h}$ ), and the patient was hospitalised for further examinations. Captopril challenge test revealed PAC to PRA ratio of $599.5(119.9 \mathrm{pg} / \mathrm{mL} / 0.2 \mathrm{ng} / \mathrm{mL} / \mathrm{h})$ at $60 \mathrm{~min}$ and $699.5(139.9 \mathrm{pg} / \mathrm{mL} / 0.2 \mathrm{ng} / \mathrm{mL} / \mathrm{h})$ at $90 \mathrm{~min}$. Consequently, the patient was diagnosed with primary aldosteronism, although no adrenal gland tumour was detected by the abdominal CT. The patient was treated with $50 \mathrm{mg} /$ day of spironolactone following which her leg oedema improved substantially (figure 1).

Differential diagnosis of leg oedema is based on a wide range of underlying conditions; (1) systemically: failures of cardiac, liver or renal functions, malnutrition and hypothyroidism; (2) locally: pelvic tumours, skin and soft tissue infections, traumatic events, and venous thrombosis, and (3) medication: for example, calcium channel blockers. These varied but potential causes are generally distinguished based on their clinical course (acute or chronic), distribution (uni or bilateral) and correlating symptoms. Although the fluid-retaining nature of the disease, primary aldosteronism usually does not cause peripheral oedema, and thus, is not listed as a cause of leg oedema.
Our case suggested that primary aldosteronism may cause insistent leg oedema. In addition to the results of endocrinological examinations, the effectiveness of spironolactone (but not loop diuretics) in the improvement of persistent leg oedema strengthened the certainty of the diagnosis. The patient's symptoms progressed silently without hypertension, leading to a delay in the appropriate diagnosis. A possible mechanism for the absence of oedema in primary aldosteronism may be due to a so-called mineralocorticoid escape, or atrial natriuretic peptide-induced natriuresis and diuresis. Briefly, activation of the ATP/UTP/P2Y2 receptor system at the level of the connecting tubules or collecting ducts increases the urine sodium concentration. This, in turn, prompts dysfunction of the epithelial sodium channel and as a consequence causes a reduction in sodium reabsorption. ${ }^{1}$ However, an association of leg oedema and the disease has been reported previously. ${ }^{2}$ Other studies have reported elevated PACs in patients with idiopathic oedema. ${ }^{3}$ Therefore, we consider that patients with primary aldosteronism possibly manifest oedema as the main presentation. It is very likely that patients with primary aldosteronism may be misdiagnosed as
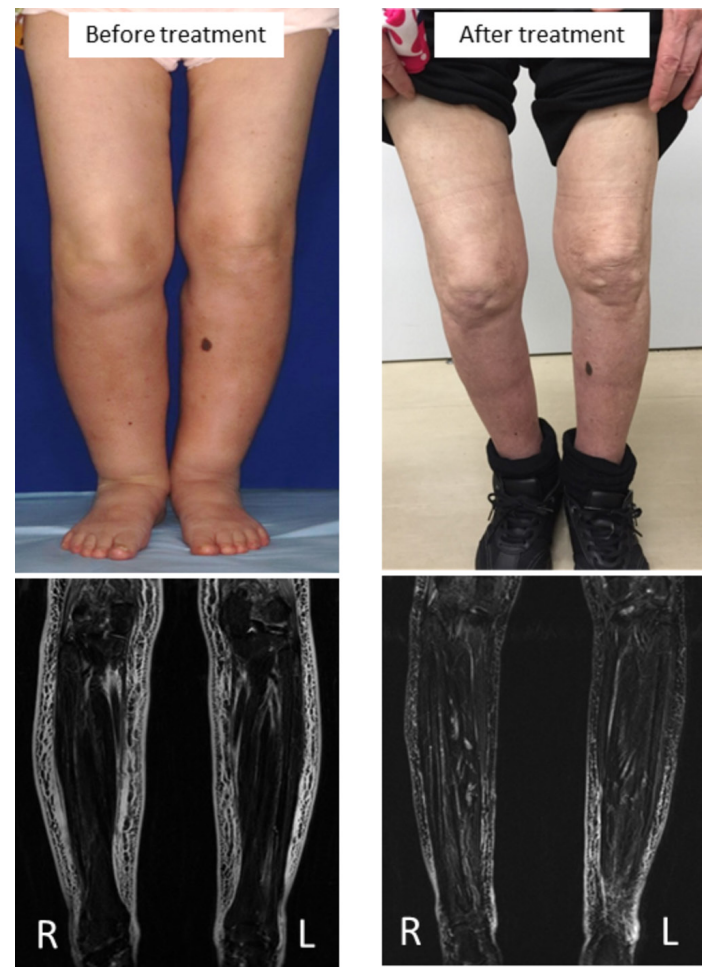

Figure 1 Macroscopic images and MRI (Short-TI Inversion Recovery) of lower extremities showing diffuse oedematous changes in subcutaneous tissue. 
idiopathic oedema. Further studies to investigate a detailed pathophysiological mechanism of the phenomenon and epidemiological relevance of the disease in patients suffering from oedema with unknown origin are warranted.

\section{Learning points}

- The patient with persistent leg oedema was correctly diagnosed with primary aldosteronism and successfully treated with an aldosterone antagonist.

- Primary aldosteronism can be an underlying disease in patients diagnosed with idiopathic oedema.
Contributors $\mathrm{TN}, \mathrm{HH}$, and FN managed the patient and wrote the manuscript. $\mathrm{KY}$ supervised.

Funding The authors have not declared a specific grant for this research from any funding agency in the public, commercial or not-for-profit sectors.

Competing interests None declared.

Patient consent for publication Not required.

Provenance and peer review Not commissioned; externally peer reviewed.

\section{REFERENCES}

1 Vallon V, Rieg T. Regulation of renal $\mathrm{NaCl}$ and water transport by the ATP/UTP/P2Y2 receptor system. Am J Physiol Renal Physiol 2011;301:F463-F475.

2 Goldsmith RS, Meroney WH, Bartter FC. Prominent peripheral edema associated with primary aldosteronism due to an adrenocortical adenoma. J Clin Endocrinol Metab 1960;20:1168-83.

3 Kay A, Davis CL. Idiopathic edema. Am J Kidney Dis 1999:34:405-23.

Copyright 2018 BMJ Publishing Group. All rights reserved. For permission to reuse any of this content visit https://www.bmj.com/company/products-services/rights-and-licensing/permissions/

BMJ Case Report Fellows may re-use this article for personal use and teaching without any further permission.

Become a Fellow of BMJ Case Reports today and you can:

- Submit as many cases as you like

- Enjoy fast sympathetic peer review and rapid publication of accepted articles

- Access all the published articles

Re-use any of the published material for personal use and teaching without further permission

For information on Institutional Fellowships contact consortiasales@bmjgroup.com

Visit casereports.bmj.com for more articles like this and to become a Fellow 